\title{
Nadir CD4+, religion, antiretroviral therapy, incidence of type 2 diabetes mellitus, and increasing rates of obesity among black Africans with HIV disease
}

This article was published in the following Dove Press journal: International Journal of General Medicine

22 November 2012

Number of times this article has been viewed

\section{Madone Mandina Ndona' Benjamin Longo-Mbenza ${ }^{2}$ Roger Wumba ${ }^{3}$ Barthelemy Tandu Umba ${ }^{4}$ Baudouin Buassa-bu- Tsumbu $^{5}$ Marcel Mbula Mambimbi ${ }^{1}$ Thaddée Odio Wobin' Simon Mbungu Fuele ${ }^{6}$}

'Department of Internal Medicine, University of Kinshasa, Kinshasa, Democratic Republic of Congo; ${ }^{2}$ Walter Sisulu University, Faculty of Health Sciences, Mthatha, Eastern Cape, South Africa; ${ }^{3}$ Tropical Medicine Department, Infectious and Parasitic Diseases, University Clinic of Kinshasa and University of Kinshasa, Kinshasa, Democratic Republic of Congo; ${ }^{4}$ Department of Gynecology, ${ }^{5}$ Department of Biochemistry, University of Kinshasa, Kinshasa, Democratic Republic of Congo; ${ }^{6}$ Biostatistics Unit of Lomo Medical Center and Heart of Africa Center of Cardiology, Kinshasa, Democratic Republic of Congo
Correspondence: Benjamin Longo-Mbenza Walter Sisulu University, Faculty of Health Sciences, Private Bag XI, Mthatha 5I I7, Eastern Cape, South Africa Tel +27732822843

Email longombenza@gmail.com
Background: The purpose of this study was to determine the cross-sectional association between some sociodemographic factors and antiretroviral therapy (ART), as well as the incidence and predictors of type 2 diabetes mellitus among Central Africans with human immunodeficiency virus (HIV) disease.

Methods: This study had a cross-sectional design and was a prospective analysis of 102 patients with HIV disease (49 on ART versus 53 not on ART) in Kinshasa, Democratic Republic of Congo, between 2004 and 2008. A Cox regression model was used to assess for any relationship between type 2 diabetes and exposure to combination ART without protease inhibitors, after adjusting for known risk factors for type 2 diabetes, nadir CD4 and CD8 levels, viral load, marital status, and religion.

Results: Unexpectedly elevated rates of smoking, excess alcohol intake, and ART-related total, abdominal, and peripheral obesity were observed in our study group of HIV patients. At the end of follow-up, five patients were diagnosed with type 2 diabetes (incidence rate 4.9\%, 9.8 per 1000 person-years). Univariate risk factors for type 2 diabetes were male gender (relative risk [RR] 1.1, 95\% confidence interval [CI] 1.01-1.4; $P=0.019$ ), traditional religion versus new charismatic religion (RR 1.1, 95\% CI 1.01-1.3; $P=0.046$ ), exposure to ART (RR 1.1, 95\% CI 1.002-1.3; $P=0.034$ ), and single status (RR 6.2, 95\% CI 1.5-15; $P=0.047$ ). In multivariate analysis, strong significant independent predictors of type 2 diabetes were belonging to a traditional religion (HR 2.1, 95\% CI 1.1-4.2; $P=0.036$ ) and a relative increase in nadir CD4 cell count (beta coefficient $0.003 ; P<0.0001$ ).

Conclusion: ART-related obesity and type 2 diabetes are becoming increasing problems in Central Africans with HIV disease. A relative increase in nadir CD4 count and traditional religion status appear to be the strongest independent predictors of type 2 diabetes.

Keywords: human immunodeficiency virus, diabetes mellitus, risk factors, Africans, religion

\section{Introduction}

Human immunodeficiency virus (HIV) infection has become associated with decreased morbidity and mortality since the advent of highly active antiretroviral therapy (HAART) in Western countries, ${ }^{1}$ non-Western Asian settings, ${ }^{2,3}$ and sub-Saharan regions. ${ }^{4}$ However, older age, HIV infection itself, antiretroviral therapy (ART), HIVrelated inflammation, current CD4 T cell count, nadir CD4 T cell count $<350$ cells $/ \mathrm{mm}^{3}$, and traditional risk factors for cardiovascular disease (smoking, obesity, physical inactivity, excess alcohol intake) substantially increase the risk of cardiovascular disease, 
including hypertension, stroke, coronary artery disease, peripheral artery disease, dyslipidemia, diabetes mellitus, metabolic syndrome, and lipodystrophy. ${ }^{5-17}$

The occurrence of chronic HAART-associated noncommunicable diseases is attributable to complex molecular mechanisms, including the direct impact of HAART on lipid metabolism, endothelial and adipocyte cell function, and mitochondria. ${ }^{18}$

Experts have dichotomized the nadir CD4 T cell count into $<350$ cells $/ \mathrm{mm}^{3}$ versus $\geq 350$ cells $/ \mathrm{mm}^{3}$ to define the optimal time to start ART. ${ }^{19-21}$ Changes in CD4 counts from very low levels to at least 200 cells $/ \mathrm{mm}^{3}$ reduce the frequency of progression of HIV disease. ${ }^{22}$ In HIV patients of black African descent, psychosocial determinants, including new charismatic religion, significantly delay progression of the disease to acquired immune deficiency syndrome (AIDS). ${ }^{23-25}$

In developed countries, rates of type 2 diabetes mellitus and insulin resistance ${ }^{12}$ have been increasing among HIVinfected patients after the introduction of HAART. In these settings, the incidence of type 2 diabetes among patients with HIV disease receiving protease inhibitors and other antiretroviral molecules is estimated to be $1 \%-13 \%{ }^{7,13-15}$ Causes of type 2 diabetes in HIV-infected patients are complex, and include the effects of HIV, which is a chronic inflammatory and insulin-resistant condition in itself, genetics, cigarette smoking, physical inactivity, obesity, and aging. ${ }^{16}$

However, in sub-Saharan Africa, with the exception of South Africa, ${ }^{4}$ ART in general and protease inhibitors in particular are not readily available at present. Only $6 \%$ of HIV-infected patients have had access to generic ART since 2004. ${ }^{26}$ In the Democratic Republic of Congo, combination ART is defined as at least triple therapy including two nucleoside reverse transcriptase inhibitors (stavudine + lamivudine or zidovudine + lamivudine) plus one non-nucleoside reverse transcriptase inhibitor (nevirapine or efavirenz).

There are many reports of the increasing prevalence, incidence, and risk factors for type 2 diabetes in general populations, ${ }^{27-31}$ but we do not have data about the disease in HIV patients from the Democratic Republic of Congo who have progressed to AIDS. Therefore, the objective of this study was to determine the cross-sectional association between a number of sociodemographic factors and ART, and the incidence and predictors of type 2 diabetes among Central Africans with HIV disease.

\section{Materials and methods}

This study was of mixed design and included both a cross-sectional analysis of baseline sociodemographic, cardiometabolic, and HIV characteristics (CD4, nadir CD4, CD8, HIV-1 RNA, and combination ART) and a longitudinal analysis of nadir CD4 count and the incidence of new-onset type 2 diabetes mellitus while on combination ART at 3-monthly intervals during the study.

The study included two groups of patients (exposed or not exposed to ART) followed up at the Teaching Hospital of Kinshasa University Medical School, Democratic Republic of Congo, between January and December 2008. The institutional research board/ethics committee of Kinshasa University approved the study protocol, which complied with the Declaration of Helsinki. Informed consent was obtained from all participants. A total of at least $87 \mathrm{HIV}$-infected patients aged $\geq 18$ years was needed in each group to give the study sufficient power to detect such an increase in risk (smaller incidence in one group $=0.01$; higher incidence in the other group $=0.11$; two-sided type I error, $\alpha=0.10$; power $80 \%$, http://www.epibiostat.ucsf.edu/dcr/).

Patients were followed prospectively during their regular visits to outpatient or inpatient services. At enrolment (baseline in 2004) and at least every 3 months thereafter, standardized data collection forms were completed to provide information about gender, age, family and personal history of diabetes, cigarette smoking, alcohol intake, physical inactivity, marital status, religion, anxiety (stress, death of spouse, lack of social support), socioeconomic status, blood pressure, treatment for diabetes, lipid-lowering therapy, antihypertensive therapy, and any other sexually transmitted infections.

At baseline, a comprehensive evaluation was performed, including measurements of weight, height, body mass index (BMI, kg/height in $\mathrm{m}^{2}$ ), waist circumference, hip circumference, systolic blood pressure, diastolic blood pressure, CD4 cell count, CD8 cell count, viral load (HIV-RNA level), total cholesterol, cumulative exposure to ART (months), and duration of HIV-1 infection (years).

At enrolment and during each longitudinal visit, an oral glucose tolerance test was performed after an 8-14-hour fast overnight, with a standard oral load of $75 \mathrm{mg}$ glucose in 250-300 mL water, and glucose determination on arrival and after 2 hours using hexokinase-glucose- 6 phosphate dehydrogenase (Biomerieux, Marcy l'Etoile, France) and an autoanalyzer (Hospitex Diagnostics, Florence, Italy) at the same central laboratory at Lomo Medical, Kinshasa Limete Democratic Republic of Congo (variation coefficient of intratest and intertest for plasma glucose being $1.3 \%$ and $1.6 \%$, respectively).

All the information collected was transported into a standardized format and merged into a central data set at the 
Clinical Epidemiology Unit, Lomo Medical Center, Kinshasa Limete, Democratic Republic of Congo. The data merged in December 2008 are presented in this study.

All incidental cases of type 2 diabetes were reported to the study coordinating office at Lomo Medical Center for central validation and coding. All new-onset cases were identified in one of two ways, ie, a definite diagnosis if fasting plasma glucose was $\geq 126 \mathrm{mg} / \mathrm{dL}(7.0 \mathrm{mmol} / \mathrm{L})$ and/or $2 \mathrm{H}$-glucose post load plasma glucose was $\geq 200 \mathrm{mg} / \mathrm{dL}$ (11.1 mmol/L).

\section{Definitions}

Diabetes mellitus was defined according to World Health Organization (WHO) criteria, ie, fasting plasma glucose $>126 \mathrm{mg} / \mathrm{dL}(7.0 \mathrm{mmol} / \mathrm{L})$ measured on two consecutive occasions. High and low socioeconomic status were defined according to our previous population-based survey. ${ }^{8}$ HIV disease staging was defined according to WHO criteria ${ }^{11}$ and Centers for Disease Control and Prevention classification. ${ }^{12}$

Nutritional status included underweight (BMI < 18.5), ideal weight (BMI 18.5-24.9), overweight (BMI 25-29.9), and obesity ( $\mathrm{BMI} \geq 30$ ). Therefore, $\mathrm{BMI} \geq 25$ (overweight/ obesity) defined total obesity versus abdominal obesity with waist circumference $\geq 94 \mathrm{~cm}$, a Congolese populationspecific cutoff for both men and women as a surrogate of clinical insulin resistance, ${ }^{13}$ and peripheral obesity with hip circumference $\geq 97 \mathrm{~cm}$, a Congolese population-specific cutoff for both men and women. ${ }^{14}$

Lifestyle factors (cigarette smoking, physical inactivity, excessive alcohol intake) were defined according to the WHO STEPwise approach. ${ }^{15}$ Religion was divided in groups, ie, one comprising the new charismatic religion imported from
African-American churches (miracles, positive coping) and another group comprising the traditional churches (Catholic, Protestant, Muslim). In the Democratic Republic of Congo, ART strategies include a combination of stavudine + lamivudine, zidovudine + lamivudine + nevirapine, or efavirenz. High cardiovascular risk was defined as elevated rates of cigarette smoking, alcohol intake, abdominal obesity, overweight/total obesity, and peripheral obesity.

\section{Statistical analysis}

Data were expressed as the mean \pm standard deviation for continuous variables or as proportions (\%) for qualitative variables. Means and proportions were compared using the Student's $t$-test and the Chi-square test, respectively. Trends of proportions were examined using linear-by-linear Chi-square tests $(P$ for trend). In univariate analysis, the relative risk of type 2 diabetes and its 95\% confidence interval (CI) was calculated (Mantel-Haenszel test). In multivariate analysis, the Cox regression model was used to quantify the relationship (hazards ratio and its $95 \% \mathrm{CI}$ ) between exposure to ART, other univariate potential risk factors, and the risk of type 2 diabetes after adjustment for possible differences in the participant cardiometabolic risk profile. Data were regarded as statistically significant when the $P$-value was $<0.05$ (two-tailed test). All statistical analyses were performed using Statistical Package for the Social Sciences (SPSS) software for Windows version 13.0 (IBM Corporation, Armonk, NY).

\section{Results}

Of 174 eligible patients with HIV disease, 102 patients with complete data (response rate 58.6\%) participated in this longitudinal cohort. The study population included

Table I Baseline sociodemographic characteristics of patients according to exposure to antiretroviral therapy at baseline

\begin{tabular}{|c|c|c|c|c|}
\hline Variables & All n (\%) & With exposure to ART n (\%) & Without exposure to ART n (\%) & $P$-value \\
\hline \multicolumn{5}{|l|}{ Gender } \\
\hline - Men & $50(49)$ & $21(42.9)$ & $29(54.7)$ & 0.231 \\
\hline - Women & $52(5 I)$ & $28(57.1)$ & $24(45.3)$ & \\
\hline Current smokers & II (I0.8) & $4(8.2)$ & $7(\mid 3.2)$ & 0.412 \\
\hline Excessive alcohol intake & $16(15.2)$ & $7(\mid 4.3)$ & $9(17)$ & 0.708 \\
\hline Physical inactivity & $83(81.4)$ & $42(85.7)$ & $4 I(77.4)$ & 0279 \\
\hline \multicolumn{5}{|l|}{ Marital status } \\
\hline - Married & $42(4 \mid .2)$ & $21(42.9)$ & $21(39.6)$ & 0.704 \\
\hline - Nonmarried & $60(58.8)$ & $28(57.1)$ & $32(60.4)$ & \\
\hline \multicolumn{5}{|l|}{ Socioeconomic status } \\
\hline - High & $28(27.5)$ & $13(26.5)$ & $15(28.3)$ & 0.841 \\
\hline - Low & $74(72.5)$ & $36(73.5)$ & 38 (7I.7) & \\
\hline Multiple sexual partners & $50(49)$ & $23(46.9)$ & $27(50.9)$ & 0.686 \\
\hline New charismatic religion & $44(43.1)$ & $24(49)$ & $20(37.7)$ & 0.252 \\
\hline Anxiety & $16(15.2)$ & 7 (I4.3) & $9(17)$ & 0.708 \\
\hline
\end{tabular}

Abbreviation: ART, antiretroviral therapy. 
Table 2 Comparing mean baseline levels of continuous variables according to exposure to ART at baseline

\begin{tabular}{|c|c|c|c|c|}
\hline Variable of interest & All mean \pm SD & With ART exposure mean \pm SD & Without ART exposure mean \pm SD & $P$-value \\
\hline Age (years) & 43.4 & $43 \pm 9.2$ & $43.6 \pm 13.3$ & 0.874 \\
\hline BMI $\left(\mathrm{kg} / \mathrm{m}^{2}\right)$ & $23.1 \pm 4.1$ & $23.1 \pm 4.1$ & $23 \pm 4$ & 0.855 \\
\hline WC $(\mathrm{cm})$ & $83.2 \pm 13.9$ & $84.9 \pm 12.2$ & $82 \pm 12.6$ & 0.770 \\
\hline $\mathrm{HC}(\mathrm{cm})$ & $89.8 \pm 13.9$ & $87.6 \pm 8.4$ & $92.5 \pm 13.9$ & 0.442 \\
\hline $\mathrm{SBP}(\mathrm{mmHg})$ & $116.2 \pm 19.7$ & $113.6 \pm 19.4$ & $118.5 \pm 19.9$ & 0.214 \\
\hline $\mathrm{DBP}(\mathrm{mmH} \mathrm{g})$ & $70.8 \pm 19.7$ & $70.4 \pm 13.3$ & $71.1 \pm 13.6$ & 0.751 \\
\hline FPG (mg/dL) & $64 \pm 21.6$ & $96.6 \pm 24.6$ & $96.1 \pm 16.3$ & 0.340 \\
\hline $2 \mathrm{H}-\mathrm{FPG}(\mathrm{mg} / \mathrm{dL})$ & $106.9 \pm 30$ & $118 \pm 32.5$ & $104.9 \pm 124$ & 0.451 \\
\hline CD4 cells $/ \mathrm{mm}^{3}$ & $167.2 \pm 113.4$ & $169.8 \pm 95.1$ & $161.6 \pm 124$ & 0.772 \\
\hline CD8 cells $/ \mathrm{mm}^{3}$ & $819.6 \pm 551.6$ & $755.5 \pm 205.8$ & $8801 \pm 740.9$ & 0.259 \\
\hline HIV-I RNA (copies/mL) & $|44280 \pm 22243|$ & $131839 \pm 174269$ & $15296 \pm 251927$ & 0.660 \\
\hline
\end{tabular}

Abbreviations: ART, antiretroviral therapy; BMI, body mass index; DBP, diastolic blood pressure; SBP, systolic blood pressure; FPG, fasting plasma glucose; HC, hip circumference; WC, waist circumference; SD, standard deviation.

49 patients infected with HIV-1 and exposure to combination ART and 53 patients infected with HIV-1 not on combination ART. The mean known duration of HIV-1 infection was $3.8 \pm 1.8$ years in the study population and in each exposure group. The mean cumulative duration of exposure to ART was $25 \pm 15$ months.

Tables 1 and 2 show the baseline characteristics of the HIV patients at entry into the study and stratified by their ART exposure. Patients on and not on combination ART were comparable $(P>0.05)$ for general baseline characteristics. All patients had baseline nadir CD4 cells $<200 \mathrm{~mm}^{3}$.

Figure 1 shows the distribution of the study population at study entry according to nutritional status and ART exposure. It shows unexpectedly low rates of underweight, with two thirds of participants being of ideal normal weight and one third being overweight or obese. Rates of abdominal obesity $(39.6 \%, n=40)$ and peripheral obesity $(36.3 \%, \mathrm{n}=37)$ were also high among these patients with HIV disease. Abdominal and peripheral obesity were more prevalent in patients with ART exposure (peripheral obesity in $55.1 \%, P=0.002$; abdominal obesity in $63.3 \%, P<0.01)$ than in patients without ART exposure (peripheral obesity in $18.9 \%$, and

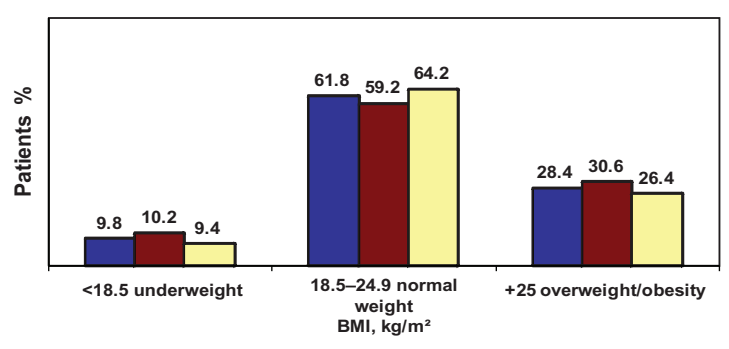

Figure I Distribution of the study population, including patients exposed and not exposed to antiretroviral therapy according to nutritional status.

Notes: Blue = all participants; brown = patients exposed to antiretroviral therapy; yellow $=$ patients not exposed to antiretroviral therapy. abdominal obesity in 17\%). Paradoxically, abdominal obesity/clinical insulin resistance was present in patients who were underweight, of normal weight, and with overweight/ total obesity (Figure 2). At 3-month follow-up, changes in nadir CD4 count from less than to more than $200 / \mathrm{mm}^{3}$ occurred in 45 patients on combination ART $(98.8 \%)$ and in three patients not on combination ART (5.7\%), and the difference was statistically significant $(P<0.0001)$.

Significantly lower rates of anxiety, smoking, and excess alcohol intake but higher values for HIV duration and baseline CD4 counts were present in patients following new charismatic religion than those following a traditional religion $(P<0.0001$, Table 3$)$. Other characteristics were similar across both study groups (results not shown).

Overall, five of 102 patients developed new-onset type 2 diabetes (rate $4.9 \%$ or 9.8 per 1000 person-years). Male gender, following a traditional religion, an increase in nadir CD4 count, exposure to ART, and single status were identified as significant univariate risk factors for incident cases of type 2 diabetes (Table 4). However, after multivariate analysis and adjustment for gender, ARV exposure and marital status, only changes in increased nadir CD4 count and following a traditional religion independently predicted onset of type 2 diabetes (Table 5).

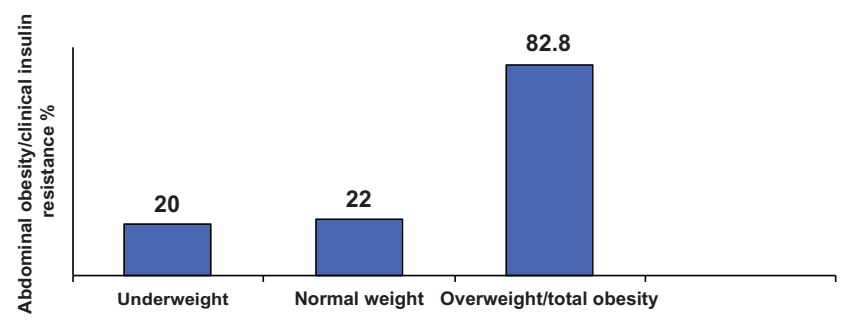

Figure 2 Distribution of abdominal obesity/clinical insulin resistance according to nutritional status of patients. 
Table 3 Distribution of important variables by religion

\begin{tabular}{|c|c|c|c|}
\hline Important variables & $\begin{array}{l}\text { NCR }(n=44) \\
n(\%) \text { or mean } \pm \text { SD }\end{array}$ & $\begin{array}{l}\text { Traditional religion }(n=58) \\
n(\%) \text { or mean } \pm \text { SD }\end{array}$ & $P$-value \\
\hline Anxiety & $4(9.9)$ & $12(20.7)$ & $<0.0001$ \\
\hline Smoking & I (2.3) & $10(17.2)$ & $<0.0001$ \\
\hline Excessive alcohol intake & $2(4.6)$ & $14(24.1)$ & $<0.0001$ \\
\hline HIV duration (years) & $4.2 \pm 2.2$ & $2.1 \pm 1.6$ & $<0.0001$ \\
\hline CD4 & $264 \pm 115.2$ & $145.4 \pm 94.2$ & $<0.0001$ \\
\hline
\end{tabular}

Abbreviations: HIV, human immunodeficiency virus; NCR, new charismatic religion; SD, standard deviation.

\section{Discussion}

The data show that these African HIV patients are at high cardiovascular risk because of unexpectedly elevated rates of total obesity, smoking, excess alcohol intake, abdominal obesity, peripheral obesity, and physical inactivity. Physical inactivity and social stigma may explain the high rates of obesity in our study because there was not significant association between anthropometry, total cholesterol, and exposure to ART at the entry. This study demonstrated that before introduction of ART in 2004, no cases of diabetes mellitus were reported among these HIV-infected patients. HIV infection on its own was previously thought to be a significant protective factor against the onset of diabetes. However, although protease inhibitors were not available to these patients, the present study has shown an increased risk of type 2 diabetes amongst them, as reported elsewhere. ${ }^{7,13-15,32-34}$ The estimated incidence rate of $4.9 \%$ ( 9.8 per 1000 person-years) of type 2 diabetes in the present cohort remains within the interval

Table 4 Univariate association of combination antiretroviral therapy and other cardiometabolic risk factors with the incidence of type 2 diabetes

\begin{tabular}{|c|c|c|c|c|}
\hline Variable of interest & $\mathbf{n}$ & $\%$ & RR (95\% Cl) & $P$-value \\
\hline \multicolumn{5}{|c|}{ Incidence of type 2 diabetes } \\
\hline \multicolumn{5}{|l|}{ Gender } \\
\hline - Men & 5 & 10 & I.I (I.0I-I.4) & 0.019 \\
\hline - Women & 0 & 0 & & \\
\hline \multicolumn{5}{|l|}{ Religion } \\
\hline - Traditional & 5 & 8.6 & I.I (I.0I-I.3) & 0.046 \\
\hline - New charismatic & 0 & 0 & & \\
\hline \multicolumn{5}{|l|}{ ART exposure } \\
\hline - Yes & 4 & 8.6 & I.I (I.002-I.3) & 0.064 \\
\hline - No & 1 & 1.9 & & \\
\hline \multicolumn{5}{|l|}{ Marital status } \\
\hline - Nonmarried & 4 & 9.5 & $6.2(1.5-15)$ & 0.047 \\
\hline - Married & 1 & 1.7 & & \\
\hline \multicolumn{5}{|l|}{ At 3 months } \\
\hline ART changes of nadir CD4 & 5 & 10 & $1.1(1.1-1.4)$ & 0.019 \\
\hline \multicolumn{5}{|l|}{ Shift to $>200 / \mathrm{mm}^{3}$} \\
\hline Constant to $<200 / \mathrm{mm}^{3}$ & 0 & 0 & & \\
\hline
\end{tabular}

Abbreviations: ART, antiretroviral therapy; RR, relative risk. of $1 \%-13 \%$ reported in Africa. ${ }^{13-15,35}$ In Western countries, cardiometabolic effects related to protease inhibitors are well known in HIV patients. ${ }^{35,36}$ However, the incidence was lower than the $17-47$ per 1000 person-years of incident cases of diabetes in the multicenter AIDS cohort study. ${ }^{36}$ Ethnicity, sample size, criteria used to define diabetes (a single elevated fasting blood glucose measurement), treatment with protease inhibitors, demographic composition (older age), and higher BMI may explain the differences in incidence rates for diabetes among HIV patients and across the continents. In the US, protease inhibitors increase the likelihood of diabetes developing with age in African-Americans infected with HIV. ${ }^{34}$

Our results are consistent with those of other cohorts showing a similar relationship between exposure to ART without protease inhibitors, ${ }^{16,35,36}$ older age, male gender, ${ }^{35}$ and incidence of type 2 diabetes. Indeed, older age, cigarette smoking, and excess alcohol intake are well established risk factors for diabetes among HIV patients..$^{35}$

Single status may constitute a stress/anxiety with hypersympathicotonia, which is known to determine hyperglycemia. As in people not infected with HIV, age is an important risk factor for both diabetes and coronary heart disease in people with HIV in developed countries. ${ }^{37}$ The nucleoside reverse transcriptase inhibitors may contribute to a higher risk of diabetes in Central Africans with HIV via different mechanisms. There was a significant association between abdominal obesity (a surrogate for clinical insulin resistance

Table 5 Adjusted hazards ratio of new-onset of type 2 diabetes in patients with HIV disease

\begin{tabular}{llll}
\hline $\begin{array}{l}\text { Independent variables } \\
\text { at study entry }\end{array}$ & $\begin{array}{l}\text { Beta } \\
\text { coefficient }\end{array}$ & SE & $\begin{array}{l}\text { HR } \\
\mathbf{( 9 5 \% ~ C l )}\end{array}$ \\
\hline $\begin{array}{l}\text { Changes of nadir } \\
\text { CD4 cell count }\end{array}$ & 0.003 & 0.001 & $\begin{array}{l}1.003 \\
(1.00 I-1.005)\end{array}$ \\
$\begin{array}{l}\text { Religion } \\
\text { Traditional versus NCR }\end{array}$ & $0.74 \mathrm{I}$ & 0.354 & $2.1(\mathrm{I} . \mathrm{I}-4.2)$ \\
\hline
\end{tabular}

Abbreviations: $\mathrm{Cl}$, confidence interval; HIV, human immunodeficiency virus; $\mathrm{HR}$, hazards ratio; SE, standard error; NCR, new charismatic religion. 
in this ethnic group), peripheral obesity, and exposure to ART. Although the mechanisms of action by which protease inhibitors and nucleoside analogs trigger diabetes is not fully understood, most of the hypothesized pathophysiology implicates the insulin resistance pathway ${ }^{16,17}$ rather than insulin secretion. ${ }^{38}$

It is important to highlight that exposure to ART had no significant effect on CD4 counts in this study. This means that other factors, such as effective control of HIV-related opportunistic infections, appropriate diet (vitamins), and reduced stress may increase the CD4 count, ${ }^{39}$ including the nadir CD4 count during the early stages of ART in HIV patients with CD4 counts $>350$ cells $/ \mathrm{mm}^{3}$ and during monitoring of treatment, ie, clinical pharmacovigilance. Indeed, treatment-naïve HIV patients in the same area of Kinshasa and practicing new charismatic religion imported from the US receive more social support, have lower rates of depression and stress, and are less likely to progress to AIDS than their counterparts practicing the more traditional religions. ${ }^{23-25,39}$ This may explain the higher risk for new-onset type 2 diabetes in HIV patients with new traditional religion. Indeed, many studies suggest that HIV itself is an inflammatory and insulin-resistant state which can precipitate overt diabetes mellitus, ${ }^{40}$ although there has been a case report of a 52-year-old African man whose type 2 diabetes resolved when viral replication was suppressed with protease inhibitor-based ART. ${ }^{41}$ Advanced HIV disease may be associated with an increase in counter-regulatory hormones whereby excess free fatty acids in the circulation reduce insulin sensitivity, hypercortisolism with further stress response as HIV disease progresses, ${ }^{42}$ growth hormone, ${ }^{43}$ high tumor necrosis factor alpha levels, ${ }^{44}$ interleukin- $6,{ }^{45}$ and HIV protein $\mathrm{Vpr}$ acting as a glucocorticoid agonist. ${ }^{46}$

Consistent with the obesity epidemic in the general population, ${ }^{29,47,48}$ the present study shows similarly increasing rates of obesity in HIV patients during the HIV pandemic. Indeed, HIV patients exposed to ART may be living longer ${ }^{49,50}$ and experiencing a lower frequency of AIDSrelated wasting syndrome. ${ }^{51-54}$ The clinical implication of the present study is that we should screen aggressively for diabetes in patients with HIV disease to avoid this double burden of disease in Africa.

\section{Conclusion}

ART-related obesity and type 2 diabetes are becoming increasing problems in Central Africans with HIV disease. A relative increase in nadir CD4 cell count and traditional religion practices appear to be the strongest independent predictors of risk of type 2 diabetes.

\section{Acknowledgment}

We thank the patients and staff at the Teaching Hospital of Kinshasa University Medical School for their assistance throughout this study.

\section{Disclosure}

The authors report no conflicts of interest in this work.

\section{References}

1. Murphy EL, Collier AC, Kalish LA, et al. Highly active antiretroviral therapy decreases mortality and morbidity in patients with advanced HIV disease. Ann Intern Med. 2001;135:17-26.

2. Wong KH, Chan KCW, Lee SS. Delayed progression to death and to AIDS in a Hong Kong cohort of patients with advanced HIV type 1 disease during the era of highly active antiretroviral therapy. Clin Infect Dis. 2004;39:853-860.

3. Chan KC, Wong KH, Lee SS. Universal decline in mortality in patients with advanced HIV-1 disease in various demographic subpopulations after the introduction of HAART in Hong Kong, from 1993 to 2002. HIV Med. 2006;7:186-192.

4. Mzileni MO, Longo-Mbenza B, Chephe TJ. Mortality and causes of death in HIV-positive patients receiving antiretroviral therapy at Tshepang Clinic in Doctor Serge Mukhari Hospital. Pol Arch Med Wewn. 2008;118:548-554.

5. Justman JE, Benning L, Danoff A, et al. Protease inhibitor use and the incidence of diabetes mellitus in a large cohort of HIV-infected women. J Acquir Immune Defic Syndr. 2003;32:298-302.

6. Brown TT, Cole SR, Li X, et al. Antiretroviral therapy and the prevalence and incidence of diabetes mellitus in the multicenter AIDS cohort study. Arch Intern Med. 2005;165:1179-1184.

7. Chu C, Umanski G, Blank A, Meissner P, Grossberg R, Selwyn PA. Comorbidity-related treatment outcomes among HIV-infected adults in the Bronx, NY. J Urban Health. 2011;88:507-516.

8. Glass TR, Ungsedhapand C, Wolbers M, et al. Prevalence of risk factors for cardiovascular disease in HIV-infected patients over time: the Swiss HIV cohort study. HIV Med. 2006;7:404-410.

9. Galli L, Salpietro S, Pellicciotta G, et al. Risk of type 2 diabetes among HIV-infected and healthy subjects in Italy. Eur J Epidemiol. Epub June 22, 2012.

10. Ho JE, Scherzar R, Hecht FM, et al. The association of CD4+ T-cell counts and cardiovascular risk in treated HIV disease. AIDS. 2012;26: $1115-1120$.

11. Longo-Mbenza B, Nkoy Belila J, Vangu Ngoma D, Mbungu Fuele S. Prevalence and Risk factors of arterial hypertension among urban Africans in Workplace: the obsolete role of body mass index. Niger $J$ Med. 2007;16:42-49.

12. Hadigan C, Meigs JB, Corcoran C, et al. Metabolic abnormalities and cardiovascular disease risk factors in adults with HIV infection and lipodystrophy. Clin Infect Dis. 2001;32:130-139.

13. Lee JC. Altered glucose metabolism in HIV-infected patients treated with HAART. $J$ Pharm Pract. 2004;17:80-86.

14. Dube MP. Disorders of glucose metabolism in patients infected with human immunodeficiency virus. Clin Infect Dis. 2000;31: $1467-1475$.

15. Carr A, Samaras K, Thorisdottir A, Kaufman GR, Chisholm DJ, Cooper DA. Diagnosis, prediction, and natural course of HIV-1 protease-inhibitor-associated lipodystrophy, hyperlipidaemia and diabetes mellitus: a cohort study. Lancet. 1999;353: 2093-2099.

16. Ledergerber B, Furrer H, Rickenbach M, et al. Factors associated with the incidence of type 2 diabetes mellitus in HIV-infected participants in the SWISS HIV cohort study. J Infect Dis. 2007;45: $111-119$. 
17. Idiculla J, Ravindra'n GD, D'Souza J, Singh G, Furruqh S. Diabetes mellitus, insulin resistance, and metabolic syndrome in HIV-positive patients in South India. Int J Gen Med. 2011;4:73-78.

18. Barbaro G. Metabolic and cardiovascular complications of highly active antiretroviral therapy for HIV infection. Curr HIV Res. 2006;4 79-85.

19. Hommes MJ, Romijin JA, Ender E, et al. Insulin sensitivity and insulinclearance in human immunodiciency virus infected men. Metabolism. 1991;40:651-656.

20. Koeppe J, Kosmiski L. Apparent Resolution of type 2 Diabetes Mellitus after Initiation of potent Antiretroviral therapy in a Man from Africa with HIV Infection. Clinical Infectious Disease. 2006;42:e79-e81.

21. World Health Organization. Antiretroviral therapy for HIV infection in adults and adolescents. 2009:1-28.

22. Miller V, Mocroft A, Reiss P, et al. Relations among CD4 lymphocyte count nadir, antiretroviral therapy, and HIV-1 disease progression: results from the EuroSIDA Study. Ann Intern Med. 1999;130:570-577.

23. Lelo MG, Mampunza MM, Longo-Mbenza B, et al. Psycho-social determinants of progression to AIDS among black Africans in Kinshasa, Democratic Republic of Congo. Psychiatry and Mental Health. 2012;2:1

24. Wilson PA, Wittlin NM, Munoz-Laboy M, Parker R. Ideologies of black churches in New York City and the public health crisis of HIV among black men who have sex with men. Glob Public Health. 2011;6 Suppl 2 S227-S242.

25. Pfeiffer J. Pentecostalism and AIDS treatment in Mozambique: creating new approaches to HIV prevention through anti-retroviral therapy. Glob Public Health. 2011;6 Supp1 2:S163-S173.

26. Ministry of Health. National Program Against HIV/AIDS and Other Sexually Transmitted Infections. Guidelines for Treating Adolescents and Adult HIV Infection by Antiretroviral Medication. Kinshasa: Ministry of Health; 2008.

27. World Health Organization. Acquired immunodeficiency syndrome (AIDS). Interim proposal for a WHO staging system for HIV infection and disease. Wkly Epidemiol Rec. 1990;65:221-228.

28. Centers for Disease Control and Prevention. 1993 Reversed classification system for HIV infection and expanded surveillance Case definition for AIDS among adolescents and adults. MMWR Recomm Rep. 1992;41:1-19.

29. Kasiam Lasi On'Kin JB, Longo-Mbenza B, Nge Okwe A, Kangola Kabangu N. Survey of abdominal obesities in an adult urban population of Kinshasa, Democratic Republic of Congo. Cardiovasc J Afr. 2007;18:300-307.

30. Longo-Mbenza B, Nkoy Belila J, Vangu Ngoma D, Mbungu Fuele S. Prevalence and risk factors of arterial hypertension among urban Africans in workplace: the obsolete role of body mass index. Niger $J$ Med. 2007;16:42-49.

31. STEPwise approach to surveillance. Available from: http://www.who. int/chp/steps/en/. Accessed July 30, 2007.

32. Wit S, Sabin CA, Weber R, et al. Incidence and risk factors for new onset diabetes mellitus in HIV infected patients: The D:A:D study. Diabetes Care. 2008;31:1224-1229.

33. Brown TT, Coles SR, Li X, et al. Antiretroviral therapy and the prevalence and incidence of diabetes mellitus in the multicenter AIDS cohort study. Arch Intern Med. 2005;165:1179-1184.

34. Salehian B, Bilas J, Bazangan M, Abbasian M. Prevalence and incidence of diabetes in HIV-infected minority patients on protease inhibitors. J Natl Med Assoc. 2005;97:1088-1092.

35. Iloeje UH, Yuan Y, L'Italien G, et al. Protease inhibitor exposure and increased risk of cardiovascular disease in HIV-infected patients. HIV Med. 2005;6:37-44.

36. Noor MA, Lo JC, Mulligan K, et al. Metabolic effects of indinivir in healthy HIV-seronegative men. AIDS. 2001;15:F11-F18.
37. Hommes MJ, Romijin JA, Ender E, et al. Insulin sensitivity and insulin clearance in human immunodeficiency virus infected men. Metabolism. 1991;40:651-656.

38. Koeppe J, Kosmiski L. Apparent resolution of type 2 diabetes mellitus after initiation of potent antiretroviral therapy in a man from Africa with HIV infection. Clin Infect Dis. 2006;42:e79-e81.

39. Sellmeyer DE, Grunfield C. Endocrine and metabolic disturbances in human immunodeficiency virus infection and the acquired immune deficiency Syndrome. Endocr Rev. 1996;17:518-532.

40. Bhasin S, Singh AB, Javanbakht M. Neuroendocrine abnormalities associated with HIV infection. Endocrinol Metab Clin North Am 2001;30:749-764.

41. Limone P, Biglino A, Valle M, et al. Insulin resistance in HIV-infected patients: relationship with pro-inflammatory cytokines released by peripheral leukocytes. $J$ Infect. 2003;47:52-58.

42. Reeds D, Yarasheski KE, Fontana L, et al. Alterations in liver, muscle, and adipose tissue insulin sensitivity in men with HIV infection and dyslipidemia. Am J Physiol Endocrinol Metab. 2006;290:E47-E53.

43. Refacli Y, Levy D, Winer D. The glucocorticoid receptor type $\Pi$ complex is a target of the HIV-1 Vpr gene product. Proc Natl Acad Sci US A. 1995;92:3621-3625.

44. Kino T, De Martino MV, Charmandari E, Ichijo T, Outas T, Chrousos GP. HIV-1 accessory protein Vpr inhibits the effect of insulin on the foxo subfamily of forehead transcription factors by interfering with their binding to the 14-13-3 proteins. Diabetes. 2005;54:23-31.

45. Dehout F, Haumont S, Gaham N, et al. Metabolic syndrome in Bantu subjects with type 2 diabetes from sub-Saharan extraction: prevalence, gender differences and HOMA hyperbolic product. Diab Metab Synd. 2008;2:5-1.

46. Worm SW, De Wit S, Weber R, et al. Diabetes mellitus, preexisting coronary heart disease, and the risk of subsequent coronary heart disease. Events in patients infected with human immunodeficiency virus. The data collection on adverse events of anti-HIV drugs (D:A:D Study). Circulation. 2009;119:805-811.

47. Parikh NI, Pencina MJ, Wang TJ, et al. Increasing trends in incidence of overweight and obesity over 5 decades. Am J Med. 2007;120: $242-250$.

48. Crum-Cianflone N, Roediger MP, Eberly L, et al. Increasing rates of obesity among HIV-infected persons during the HIV epidemic. PLoS One. 2010;5:e10106.

49. Antiretroviral Therapy Cohort Collaboration. Life expectancy of individuals on combination antiretroviral therapy in high-income countries: a collaboration analysis of 14 cohort studies. Lancet. 2008;272:293-299.

50. Palella FJ Jr, Delaney KM, Moorman AC, et al. Declining morbidity and mortality among patients with advanced human immunodeficiency virus infection. HIV Outpatient Study Investigators. $N$ Engl J Med. 1998;338:853-860.

51. Smit E, Skolasky RL, Dobs AS, et al. Changes in the incidence and predictors of wasting syndrome related to human immunodeficiency virus infection, 1987-1998. Am J Epidemiol. 2002;156:211-218.

52. Mocroft A, Sabin CA, Youle M, et al. Changes in AIDS-defining illnesses in a London clinic, 1987-1998. J Acquir Immune Defic Syndr. 1999;21:401-407.

53. Hodgson LM, Ghattas H, Prichitt H, et al. Wasting and obesity in HIV outpatients. AIDS. 2001;15:2341-2342.

54. Ferrando SJ, Rabkin JG, Lin SH, McElhiney M. Increase in body cell mass and decrease in wasting are associated with increasing potency of antiretroviral therapy for HIV infection. AIDS Patient Care STDS 2005;19:216-223. 


\section{Publish your work in this journal}

The International Journal of General Medicine is an international, peer-reviewed open-access journal that focuses on general and internal medicine, pathogenesis, epidemiology, diagnosis, monitoring and treatment protocols. The journal is characterized by the rapid reporting of reviews, original research and clinical studies across all disease areas.

A key focus is the elucidation of disease processes and management protocols resulting in improved outcomes for the patient. The manuscript management system is completely online and includes a very quick and fair peer-review system. Visit http://www.dovepress.com/ testimonials.php to read real quotes from published authors.

Submit your manuscript here: http://www.dovepress.com/international-journal-of-general-medicine-journal 